\title{
Health in Colombia: a system in crisis
}

W

hen Dr. Alfredo Pinzon, an internal medicine specialist, stepped into the emergency ward at Hospital Simón Bolivar Hospital in the Colombian capital of Bogotá to confer with a colleague, he had to pick his way through 60 patients waiting for care. The 14-bed ward, located in a grimy basement, resembled a Third World medical scene: grimly chaotic.

"Nobody gets turned away, which is the good thing," Pinzon says. The 280bed facility primarily serves patients covered by the Colombian government's subsidized health insurance scheme in a slum district that abuts a middle class neighbourhood. "The problem is the quality of the care they get: It is not nearly as good as at [private] hospitals that serve for people who are able to pay for health insurance."

One such private facility is the Hospital Universitario Fundación Santa Fe de Bogotá, roughly 50 blocks away, which was recently ranked among Latin America's three best hospitals by the influential business journal América Economía (http://rankings.america economia.com/2011/clinicas/).

Built on donated land with private money supplied by an American bank, the Hospital Universitario Fundación Santa Fe de Bogotá primarily serves patients who pay in cash or through private insurance, which is compulsory for the roughly $40 \%$ of Colombians who hold "formal" jobs. In theory, it should also serve the remaining $60 \%$ of Colombians, who are covered by government-subsidized insurance, which is provided free of charge.

But theory and practice are very different things, chuckles Pinzon. "It's unusual for a person with [government] subsidized insurance to go to a private hospital. Very few such people would even bother trying. And if they do, they might expect to be sent onwards, to a public hospital."

It's an indicator of raging inequities within Colombia's health care system,

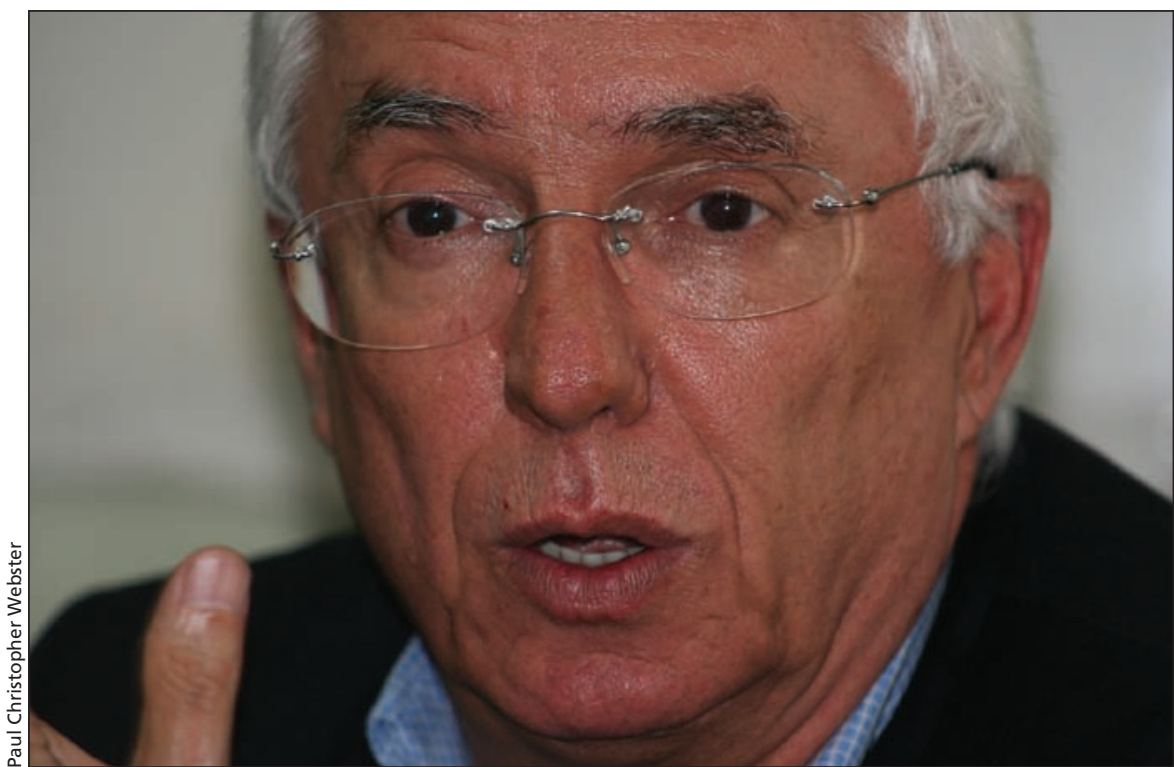

"The health system faces financial collapse, in large part because it totally lacks auditing and accountability," says Colombian Senator Jorge Enrique Robledo.

which has been lauded for providing near-universal coverage but widely criticized for providing dramatically inferior care to the less affluent. So severe is the disparity in care that two years ago, after a court order forced the government to begin paying for more equitable care, the government took the rather extraordinary legislative step of labelling the inequities a "social emergency" in order to implement changes to the financing of public health services.

The admission came almost 20 years after Colombia embarked on an ambitious effort to implement an Americanstyle "mixed-market" health care system that fused public and private delivery of health care - somehow brokered by more than 130 competing public and private health insurance companies operating much in the manner of "managed care" firms in the United States.

It allowed Colombian politicians to repeatedly boast that the system was steadily enrolling larger and larger numbers of people. By 2010, the government declared that $97 \%$ of Colombia's 44.7 million people were covered by health insurance.
According to the World Health Organization (WHO), Colombia spent $6.4 \%$ of its gross domestic product on health in 2009 , or roughly $\$ 16.3$ billion (www.who.int/countries/col/en/). In comparison, the Canadian Institute for Health Information says that Canada spent $11.6 \%$ of its gross domestic product on health in 2011, or roughly $\$ 200.5$ billion. According to the World Bank, the Colombia government covered $83.36 \%$ of overall health expenditures. In Canada, public expenditures are about $70 \%$. According to the United States Central Intelligence Agency, there were 1.35 physicians per 1000 population in Colombia in 2002 (the latest figures available), while there were 1.9132 per 1000 in Canada in 2006.

Those Colombian outlays have been increasingly bedevilled by runaway pharmaceutical costs and widespread insurance fraud, including allegations that bribes have been taken by government officials and a case in which an insurance company has been accused of spending part of its fund on a golf course and a luxury hotel. The system, in short, appears to be coming apart at the seams. 
Even President Jose Manuel Santos Calderón admitted as much in a 2011 declaration in which he noted the mixedmarket model needed reform to ensure the "basic principle which says that health cannot be a business and cannot be approached as a business. Health is a social service, is a right of Colombians" (in Spanish at: wsp.presidencia.gov .co/Prensa/2011/Agosto/Paginas/201108 12_02.aspx. Editor's translation).

The entire system is in jeopardy, argues Jorge Enrique Robledo, a crusading senator who recently uncovered a cascading series of corruption scandals within the insurance industry.

"The health system faces financial collapse, in large part because it totally lacks auditing and accountability," says Robledo, who argues that private insurance intermediaries in public health systems should be as anathema in Colombia as they are in many other nations.

Robledo also denounces "enormous abuses" in pharmaceutical costs. The international nongovernmental organization, Health Action International, and WHO indicate that Colombians pay among the highest prices in the world for some drugs, such as antiretrovirals and cephalosporin antibiotics (report in Spanish at: www.haiweb.org/medicine prices/surveys/200810CO/sdocs/Colom bia_FINAL_report_05_08_09.pdf).

Ruthless industry tactics have resulted in the use of high-priced proprietary drugs rather than generic products, says Francisco Rossi, director of IFARMA, a pharmaceutical research centre in Bogotá. It has caused govern- ment drug expenditures to quadruple since 2005, he adds. "The impact of the price explosion has created a massive crisis in our health system. It's a major reason the government declared a health care emergency two years ago."

Among the patient groups who are most affected are those with HIV, up to half of whom are systematically denied antiretrovirals, says John Harold Estada-Montaya, a drug researcher at the National University in Bogotá.

To combat high drug costs, Rossi urges the adoption of price controls, measures to promote the use of generics, restrictions on direct advertising to physicians and a ban on industry handouts to doctors to reduce industry's influence on prescription decisions.

The system suffers from "absurd organizational behavior" and "perverse" incentives that promote billing as an endpoint in care rather than improved health outcomes, argues Francisco Yepes, director of postgraduate studies in the Health and Social Security Administration at Pontificia Universidad Javeriana in Bogotá and a former advocate of mixed-market medicine. "The corrupt practices vary from insurance company to insurance company, but in general care providers do what they have to do to bill and they don't do what they can't bill for even if that is what will keep the patient alive."

As a consequence, patients with private insurance enjoy better chronic disease outcomes and lower infant and maternal mortality rates than those with government-subsidized insurance.
Private insurance should be abolished, argue Yepes, Robledo, the National Hospital Association, the National Academy of Medicine and a Commission for Health Reform established by a network of Colombian universities, various social organizations and various patient associations.

"We all believe it is time to move to a publicly funded system similar to Canada's, for example," says Yepes. "We do not want a health system run for profit."

But thus far, the Colombian government has resisted such structural change. Rather, recently appointed Health Minister Beatriz Londoño called for dramatic reforms aimed at rooting out insurance profiteering through "much tougher invoicing and accountability." She also pledged to introduce measures to contain pharmaceutical costs, including price controls and the use of international reference prices for proprietary drugs. - Paul Christopher Webster, Bogotá, Colombia

CMAJ 2012. DOI:10.1503/cmaj.109-4124

Editor's note: First of a three-part series on health in Colombia.

Part 2: Treating the displaced (www.cmaj.ca/lookup/doi/10.1503 /cmaj.109-4125).

Part 3: The chronic disease burden (www.cmaj.ca/lookup/doi/10.1503 /cmaj.109-4126). 